\title{
Stigmatization of Alcoholics and Other High-Risk Social Groups - in Relation to Gender and Type of Vocation
}

\author{
Dražen Kovačević ${ }^{1,}$ Ana Pavelić Tremac ${ }^{1}$, Tonko Carić ${ }^{2}, J^{\prime}$ ško Sindik², \\ Narcisa Manojlović ${ }^{3}$ \\ ${ }^{1}$ Neuropsychiatric Hospital Dr. Ivan Barbot, Popovača, Croatia, ${ }^{2}$ Institute of Anthropology, \\ Zagreb, Croatia, ${ }^{3}$ Ministry of Demography, Family, Youth and Social Policy, Zagreb, Croatia
}

\begin{abstract}
Apart from functional problems that arise from the fact that they belong to certain vulnerable social categories (individuals with chronic illnesses and conditions, individuals belonging to minorities and marginalized groups, etc.), members of these groups also face the feeling of distancing and/or rejection by others, including health professionals. The main purpose of this research is to determine social distances towards alcoholics compared with other high-risk social groups and to check for possible differences in social distances (and stigmatization) of alcoholics with regard to gender and occupation type. On a sample of 230 respondents (a deliberate sample of health and non-health professionals, heterogeneous by socio-demographic characteristics), using the Bogardus social distance scale, we investigated social distances for certain social groups: drug addicts, alcoholics, homosexuals, mentally ill individuals and individuals with physical disabilities. The results have shown that individuals with physical disabilities are the least stigmatized group, while the most stigmatized are drug addicts, with alcoholics being second according to social distance. A similar trend was also found in groups of subjects of different sex as well as different types of occupation, with an exception that alcoholics were the most stigmatized group among health professionals, while drug addicts were second most stigmatized group. Sexual differences in social distance towards alcoholics have not been confirmed, nor the differences between the two observed groups of occupations. The research results provide the basic guidelines needed to design the process of destigmatization of alcoholics, as well as other vulnerable social groups studied, in the populations of both health and non-health professionals of both sexes.
\end{abstract}

Keywords: high-risk social groups, alcoholics, social distance, stigma, health and non-health professionals

Copyright (C) 2020 KBCSM, Zagreb

e-mail: alcoholism.kbcsm@gmail.com •www.http://apr.kbcsm.hr

\section{Introduction}

A stigma is an accompanying and it can al-

\section{Correspondence to:}

Dražen Kovačević, PhD.

Neuropsychiatric Hospital Dr. Ivan Barbot, Jelengradska 1, 44317 Popovaca, Croatia

Phone number: +385-44-569-258

E-mail: drazen.kovacevic@bolnicapopovaca.hr most be said an integral part of many chronic diseases and conditions, which drastically intensifies the suffering of the diseased and negative consequences of illness for individuals, family and society [1]. An individual 
feels the impact of a stigma in his/her immediate surroundings, but also in educational institutions, in the workplace, in the health care system, in the legal system, and generally at the level of public bodies and government institutions [2].

One of the most famous theoretical concepts of stigmatization explains stigmatization as a result of a process involving five interrelated sequential components $[3,4]$. The first component is labelling (negative characterization on the basis of dissimilarity, for example illness), the second is stereotyping (linking labelled differences to other undesirable characteristics of an individual), the third is separation ("different individuals" which trigger suspiciousness and negative emotions are excluded from the social environment) and the fourth component is discrimination, after the previous component created the basis for devaluation, exclusion and rejection of individuals. As the key fifth component, the authors emphasize the role of power as the above-mentioned components of stigma are realized in the situation of power in relation to individuals who are attributed the lower level of value, power and influence [3].

Stigmatization combines three basic problems: the problem of knowledge, the problem of attitude (prejudice) and the problem of behaviour (discrimination) [5], so stigma(tization) is most often investigated and analysed by examining knowledge, attitudes and the consequent social distancing of individuals with a "discrediting" condition or disease [2].

One of the manifestations of negative attitudes is distancing from social contact with members of different groups. The behavioural constituent of an attitude (which may, although not necessarily, be in accordance with the emotional and cognitive compo- nent of attitude) is operationalized through social distance. The Bogardus scale of social distance [6] is based on this concept, which, with various modifications, is widely used to this day. Depending on the type of contact with a member of a group (ranging from the farthest to the closest contact) that an individual refuses, it is concluded how strongly prejudices toward that group are expressed.

As the main features distinguishing stigmatizing from non-stigmatizing diseases, the literature mentions the extent to which the disease becomes the central part of individual's identity, the severity and duration of the social consequences of the disease and the difficulty that others have in the interpretation of the symptoms [7]. Some authors interpret stigmatization with lower social valuation of sick members of the community, as they are not able to participate equally in reciprocal social exchange [8]. Some authors have considered the degree of discomfort in the social interactions that some disease causes to be the best explanation for the different degrees of social distances towards various stigmatized groups, i.e. the key determinant of stigmatization by the disease [9], and many point out either attribution of responsibility for stigmatizing illness as a key stigmatizing element or a combination of these two determinants [1]. The role of self-fulfilling prophecy in the formation of stigma was also examined, which was partly confirmed, but meta-analysis suggests only a modest contribution to the self-fulfilling prophecy in maintaining stigma [10].

Although stigmatizing humans, including those with chronic illnesses, needs to be seen in the socio-historical context and therefore as susceptible to change, this does not in any way mean that stigma of all vulnerable groups is removed in modern societies [11]. 
In developed and underdeveloped countries both, stigmatized individuals feel socially distanced and labelled, to such an extent that their quality of life is significantly reduced and their possibility of recovery is limited $[2,12]$. Therefore, no matter what mechanisms affect its emergence, stigma is considered a very important public health issue [1].

It is known that some diseases are more and some less "marking" and that there are different social distances towards them $[13,14]$. According to studies, individuals with mental disorders are perceived as more responsible for their condition than those who suffer from diseases such as cancer, cardiac problems or other health problems [15]. Criminalization of substance-using behaviours exacerbates stigma and produces exclusionary processes that further emphasize the marginalization of people who use illegal substances [16]. The use of alcohol and other drugs represents one of the behavioural conditions that suffers from moral connotations most widely $[15,17,18]$, as it is widely considered a matter of individual responsibility, and the diagnosis and treatment of dependence often exacerbates provider's moral feelings [19]. Alcohol is also viewed as a triggering mechanism for individuals who show exhibit higher propensity for violence [20]. In one Croatian study, when asked directly about social intimacy, nearly $50 \%$ of adults from the general population claimed they would not accept mentally ill individuals even as their neighbors [21]. The greatest intensity of social distance is observed in relation to individuals suffering from schizophrenia and drug addictions, while the lowest levels are observed in relation toward individuals suffering from depression, anxiety and PTSD.

When examining the relationship between stigma and gender, certain authors re- ported no significant relationship between public stigma and gender [22], while others found different, but mutually disparate results $[23,24]$. Some research reported women scored higher indicators of public stigma towards individuals with drug addiction [25], while others found that men scored higher on perceived stigma towards individuals with drug addiction [23]. In the study of stigma and alcohol disorder treatments, a higher perceived stigma was associated with males in the United States [23]. Individual studies suggest that women and those with higher income and education are generally more receptive toward individuals suffering from mental illness $[17,26]$. Although the relationship between gender and stigma is complex, individual papers hypothesize that lower endorsement of stigmatizing attitudes among women may stem from higher rates of social empathy and / or lower need for social dominance among women in comparison to men [26,27].

Although health care professionals should play a significant role in respecting patients' rights and developing understanding, many patients report stigmatization within the health system [28], which is confirmed by the results of research on stigmatization of mentally ill individuals and health professionals. The majority of studies reviewed by Schulze in MHCA 2011 and by Ahmedani found that the beliefs of mental health providers do not differ from those of the general public [29,30]. Stigmatization towards individuals with mental illness among health professionals presents obstacles to effective caregiving $[12,28,31]$. According to one study in various European countries, health professionals' regard for working with substance users, especially drug users, was consistently lower compared to other patients, such as individu- 
als suffering from other, substance-unrelated mental disorders and physical illness [32]. Alcoholism is a particularly severely stigmatized mental disorder [33].

The first goal of this study was to determine the differences in social distances towards alcoholics compared to some other socially stigmatized groups (drug addicts, homosexuals, individuals with some kind of mental illness and individuals with physical disabilities). The second goal of the research was to examine these differences with respect to participants' gender (male vs. female) and profession (non-health vs. health professionals). The extension of this goal was the investigation into the social distance between alcoholics, influenced by participants' gender and profession.

\section{Subjects and Methods}

\subsection{Method}

On a deliberate sample of health and nonhealth professionals, social distances were surveyed according to mentioned vulnerable social groups. The survey was conducted in 2015. and all respondents were introduced to its purpose and gave their consent to participate in this study.

\subsection{Instrument}

The Bogardus social distance scale, modified according to Čarija in 2008, was used to measure the readiness of participants to achieve different relationships with members of certain social groups [34]. Expecting that problem of their stigmatization will be manifested primarily when it comes to closer contact, categories of relations were selected: neighbour, friend, teacher or educator of one's own children, brother's or sister's life partner, one's own child life partner and one's own life partner, taken from a research by Jokić-Begić, Kamenov and Lauri Korajlija [21]. The task of the participant was to mark with a plus $(+)$ each relationship they would accept, and with minus (-) any relationship they would not accept for members of the particular social group. For the purposes of analysing differences between the variables examined in this study, each category of relation(ship) was attributed to a number: neighbour (1), friend (2), teacher / educator of one's own children (3) life partner (4) of one's own child (5), and one's own life partner (6). The score for each participant and for each high-risk social group was expressed as the arithmetic mean of his / her estimates for each category of relation(ship). The higher result, the greater is acceptance of a particular stigmatized group. In other words, the greater score, the smaller is social distance toward that group.

\subsection{Sample}

Out of 243 participants, 230 provided estimates of all aspects of relation(ship) they wanted or did not want with particular highrisk social group. For that reason, this sample was used in further analyses.

Participants' mean age was $\mathrm{M}=38.19$ (SD $=11.50)$. It ranged from 16 to 69 years of age. Since this study investigated social distance with respect to gender and profession, we should note that our sample consisted of 158 females (68.7\% of the overall sample) and 72 males $(31.3 \%$ of the overall sample). Non-health professionals $(n=113)$ accounted for $49.1 \%$ of the overall sample whereas health professionals made up the rest of the sample $(n=117$, i.e. $50.9 \%$ of the overall sample). 
Table 1. Socio-demographic characteristics of research subjects

\begin{tabular}{llrr}
\hline Socio-demographics & & $\mathrm{f}$ & $\%$ \\
\hline Gender & Females & 158 & 68.7 \\
(16-69 years of age) & Males & 72 & 31.3 \\
\hline Marital status & Married & 142 & 62.8 \\
& In an extra-marital relationship & 8 & 3.5 \\
& In a relationship & 35 & 15.5 \\
& Divorced & 6 & 2.7 \\
& Widow & 6 & 2.7 \\
& Single & 29 & 12.8 \\
\hline Profession & Non-health professionals & 113 & 49.1 \\
& Health professionals & 117 & 50.9 \\
\hline Educational level & Elementary and high school & 133 & 57.8 \\
& Undergraduate degree & 50 & 21.7 \\
& Graduate and postgraduate degree & 47 & 20.4 \\
\hline
\end{tabular}

Note: Missing values were not included in the calculation of percentages

\subsection{Statistical analysis}

As the Bogardus scale of social distance is the ordinal one, we have opted for nonparametric statistical procedures. As per descriptives, we have calculated sample size $(N)$, minimum and maximum estimates (scores), median $(M d n)$, and interquartile range $(I Q R)$. Wilcoxon's signature-rank test is used in testing the pairs of differences between alcoholics and other high-risk social groups. Additionally, the Mann-Whitney test was used for testing gender differences and differences in social distance toward alcoholics as influenced by participants' profession.

Reliability of the Bogardus scale of social distance (i.e. internal consistency), expressed as Cronbach's alpha coefficient amounted to $\alpha=.90$.

\section{Results}

In Table 2 and in Figure 1 obtained positive response rates (acceptance measures) are shown for each of identified groups: alcoholics, drug addicts, homosexuals, individuals with some kind of mental illness and individuals with a physical disability, and for each tested relationship: neighbour, friend, teacher or educator of one's own children, brother's or sister's life partner, one's own child life partner and one's own life partner.

It is obvious that there is the greatest social distance toward drug addicts, immediately followed by alcoholics. Individuals who have problems with alcohol or drug abuse are particularly undesirable as teachers of the children of our participants, as one's own partners (joined by homosexuals at the 
Table 2. Frequencies and relative frequencies (\%) of positive responses of participants with regard to each stigmatized group and category of relation(ship)

\begin{tabular}{lccccccc}
\hline Stigmatized group & & & & & $\begin{array}{c}\text { Brother / } \\
\text { sister's partner }\end{array}$ & $\begin{array}{c}\text { Child's } \\
\text { partner }\end{array}$ & $\begin{array}{c}\text { One's own } \\
\text { partner }\end{array}$ \\
\hline Alcoholic & $\mathrm{f}$ & 166 & 125 & 7 & 40 & 16 & 11 \\
& $\%$ & 72.2 & 54.3 & 3.0 & 17.4 & 7.0 & 4.8 \\
Drug addict & $\mathrm{f}$ & 138 & 78 & 7 & 27 & 14 & 6 \\
& $\%$ & 60.0 & 33.9 & 3.0 & 11.7 & 6.1 & 2.6 \\
Homosexual & $\mathrm{f}$ & 190 & 168 & 108 & 88 & 81 & 11 \\
Individuals with & $\mathrm{f}$ & 82.6 & 73.0 & 47.0 & 38.3 & 35.2 & 4.8 \\
mental illness & $\%$ & 185 & 176 & 37 & 73 & 53 & 50 \\
Individuals with & $\mathrm{f}$ & 223 & 225 & 207 & 176 & 159 & 153 \\
physical disability & $\%$ & 97.0 & 97.8 & 90.0 & 76.5 & 69.1 & 66.5 \\
\hline
\end{tabular}

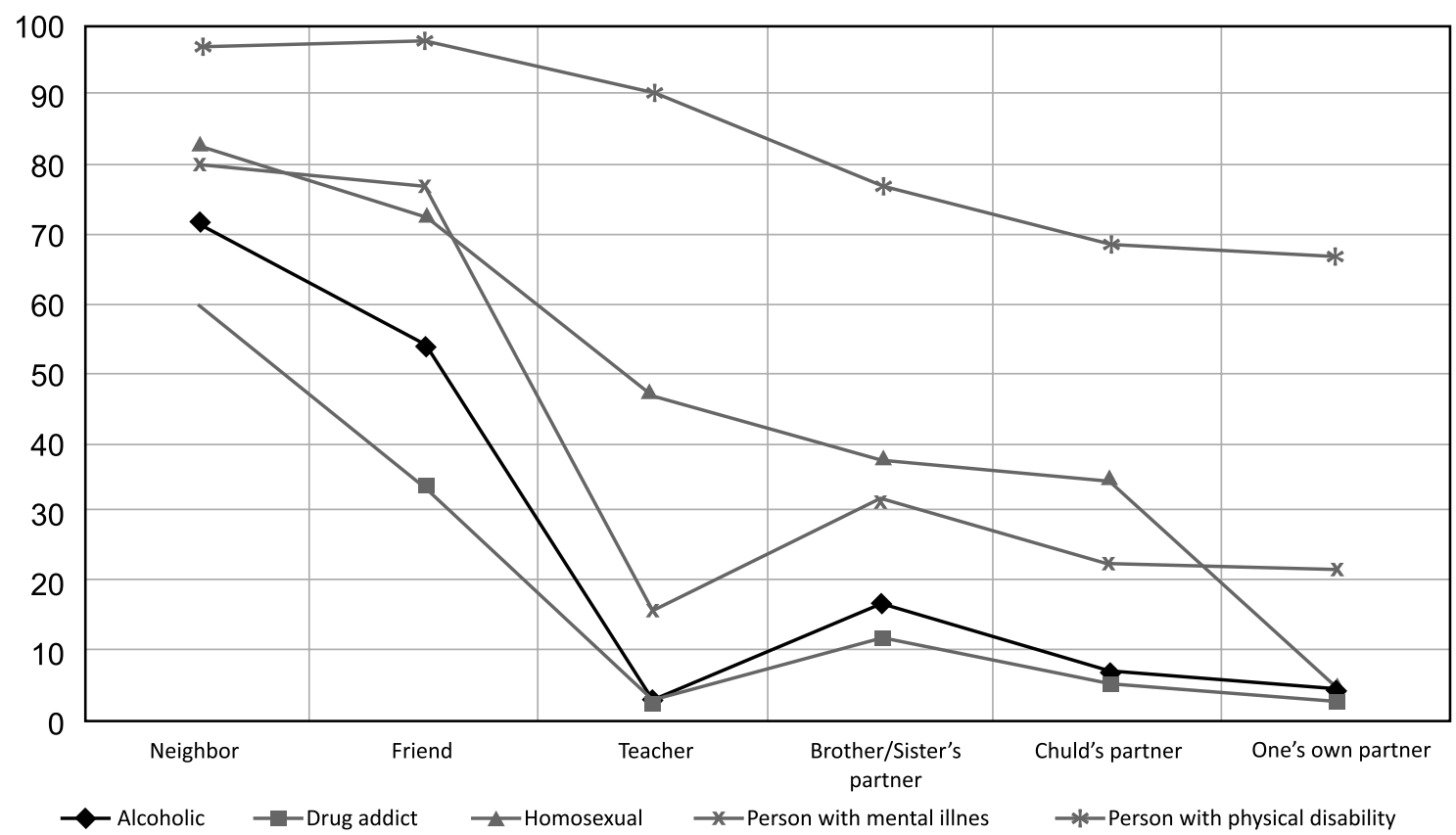

Figure 1. Relative frequencies (\%) of positive responses of the participants on Social Distance Scale according to different social groups, relative to relationship closeness 
Table 3. Descriptives for five categories of stigmatized groups (total sample)

\begin{tabular}{lccccc}
\hline Stigmatized groups & $\mathrm{N}$ & Min & Max & Mdn & IQR \\
\hline Alcoholics & 230 & 0 & 3.5 & $12: 50$ & $12: 50$ \\
Drug addicts & 230 & 0 & 3.0 & $12: 17$ & $12: 50$ \\
Homosexuals & 230 & 0 & 3.5 & $1: 00$ & $2: 33$ \\
Individuals with some mental illness & 230 & 0 & 3.5 & $12: 50$ & $1: 42$ \\
Individuals with some physical disability & 230 & 0 & 3.5 & $3: 50$ & 1.83 \\
\hline
\end{tabular}

lowest level) and as partners of brother's / sister's and children's partners. In contrast, the participants perceived the smallest social distance toward individuals with some physical disability, and all six categories of relation(ship)s (especially "neighbour" and "friends"). Alcoholics are relatively accepted only as neighbours $(72.2 \%)$ and friends $(54.3 \%)$, though even in those categories they are ranked worse than majority of other groups (except the lowest-ranked addicts). The pattern of findings with regard to alcoholics was similar to that of individuals with some mental illness (however, participants reported smaller social distance toward individuals with some mental illness). Interestingly, social distance to alcoholics and individuals with mental illness was the greatest in the case of "teacher" $(n=7$ and $n=37$, respectively) as a social role/category. It was bigger than in the case of one's own partner ( $n=11$ and $n=50$, respectively).

As already mentioned, for the purposes of the analysis of the differences between variables examined in this study, each category of relation(ship) was weighted by numbers 1 to 6 (from 1 for neighbour, to 6 for one's own life partner as the closest social relationship). As shown in Table 3, the highest median was obtained for individuals with physical disability ( $\mathrm{Mdn}=3.50)$, whereas the lowest one was obtained for drug addicts $(\mathrm{Mdn}=$ 0.17). Hence, it seemed that our participants found individuals with some physical disability most socially acceptable of all the stigmatized groups. On the other hand, they had the greatest social distance towards individuals

Table 4. Differences in social distance toward alcoholics and other stigmatized groups (total sample)

\begin{tabular}{lcccc}
\hline $\begin{array}{l}\text { Comparison between social distance } \\
\text { towards alcoholics and... }\end{array}$ & $\begin{array}{c}\text { Mean rank } \\
\text { (Positive ranks) }\end{array}$ & $\begin{array}{c}\text { Mean rank } \\
\text { (Negative ranks) }\end{array}$ & Z & p \\
\hline Drug addicts & 63.37 & 60.09 & -4742 & 0.000 \\
Homosexuals & 48.82 & 100.55 & -8566 & 0.000 \\
Individuals with some mental illness & 50.10 & 73.79 & -7545 & 0.000 \\
Individuals with some physical disability & 40.83 & 112.47 & -12.828 & 0.000 \\
\hline
\end{tabular}


Table 5. Differences in social distance toward alcoholics and other stigmatized groups (in males and females, separately)

\begin{tabular}{lcccc}
\hline $\begin{array}{l}\text { Comparison between social distance } \\
\text { towards alcoholics and... }\end{array}$ & $\begin{array}{c}\text { Mean rank } \\
\text { (Positive ranks) }\end{array}$ & $\begin{array}{c}\text { Mean ranks } \\
\text { (Negative ranks) }\end{array}$ & Z & p \\
\hline Males & & & & \\
Drug addicts & 22.65 & $19: 56$ & -3601 & 0.000 \\
Homosexuals & 20.74 & 36.14 & -2616 & 0.009 \\
Individuals with some mental illness & 15.72 & 28.27 & -3311 & 0.001 \\
Individuals with some physical disability & $15: 50$ & 35.79 & -7204 & 0.000 \\
\hline Females & & & & \\
Drug addicts & 41.04 & 40.92 & -3212 & 0.001 \\
Homosexuals & 20.97 & 65.54 & -8542 & 0.000 \\
Individuals with some mental illness & 29.67 & 47.79 & -7249 & 0.000 \\
Individuals with some physical disability & 25.00 & 77.19 & -10.634 & 0.000 \\
\hline
\end{tabular}

who have problems with drug addiction. The theoretical range of the Bogardus scale was 0 to 6; however, the maximum estimates were calculated as 3.5 (except for drug addicts, where the maximum estimate was somewhat lower, i.e. 3.0). The greatest interquartile range $(\mathrm{IQR}=2.33)$ was obtained for the social distance towards homosexuals $(\mathrm{IQR}=$
2.33), whereas the narrowest IQRs were calculated for the social distance between alcoholics and drug addicts (IQR $=0.50$ in both cases). In other words, participants shared (similar) opinions about alcoholics and drug addicts whereas their perceptions about homosexuals varied the most.

Table 6. Differences in social distance between alcoholics and other four stigmatized groups (in non-health and health professionals, separately)

\begin{tabular}{lcccc}
\hline $\begin{array}{l}\text { Comparison between social distance } \\
\text { towards alcoholics and... }\end{array}$ & $\begin{array}{c}\text { Mean rank } \\
\text { (Positive ranks) }\end{array}$ & $\begin{array}{c}\text { Mean rank } \\
\text { (Negative ranks) }\end{array}$ & Z & p \\
\hline Non-health professionals & 28.12 & 22.60 & -4355 & 0.000 \\
Drug addicts & $23: 07$ & 50.66 & -6068 & 0.000 \\
Homosexuals & 23.71 & 36.72 & -5048 & 0.000 \\
Individuals with some mental illness & $19: 50$ & 56.33 & -9126 & 0.000 \\
Individuals with some physical disability & & & & \\
Health professionals & 35.51 & 37.02 & -2456 & 0.014 \\
Drug addicts & 25.12 & 50.76 & -6151 & 0.000 \\
Homosexuals & 25.59 & 37.91 & -5729 & 0.000 \\
Individuals with some mental illness & $22: 25$ & 56.62 & -9033 & 0.000 \\
Individuals with some physical disability & & & & \\
\hline
\end{tabular}


As presented in Table 4, all differences were statistically significant. Participants perceived significantly smaller social distances towards alcoholics compared to drug addicts (the mean of positive ranks was 63.37, whereas the mean of negative ranks was $60.09, Z=-4.742, p<.001)$. In the other cases, all the means of negative ranks were significantly higher than the mean of positive ranks. Therefore, participants reported greater social distances towards alcoholics, compared to homosexuals $(Z=-8.566, p<.001)$, individuals with mental illness $(Z=-7.545, p$ $<.001)$, and individuals with physical disabilities $(Z=-12.828, p<.001)$.

By looking at the figures in Table 5, we noticed that all the differences were statistically significant (as were in the case of the total sample) in our sample of males. The pattern of results was the same. Men's social distance to alcoholics was smaller, in comparison with this type of distance to drug addicts (mean of positive ranks was greater than the mean of negative ranks, 22.65 vs. $19.56, Z=-3.601$, $p<0.001)$. In addition, the social distance toward alcoholics was greater compared to the social distance towards homosexuals ( $\mathrm{Z}=$ -2.616, $p<0.01)$, individuals with some type of mental illness $(Z=-3.311, p<0.01)$, and individuals with some physical disability $(\mathrm{Z}=$ -7.204, $p<0.001)$.

The results displayed for females were similar to those presented in Table 4. The examined differences were statistically significant in the same direction as was the case in all participants and males. Alcoholics were less stigmatized than drug addicts were $(\mathrm{Z}=$ -3.212, p <0.001), whereas they were more stigmatized compared to homosexuals, individuals with some mental illness and individuals with physical disabilities $(Z=-8.542$, $Z=-7.249, Z=-10.634$, respectively, for all of them: $p<0.001)$. Thus, the social distance to alcoholics (compared to the other four groups) was similar in the subsamples of males and females. In other words, the male or female did not yield any distinctive pattern in the obtained results.

Taking into account the data shown in Table 6, we noticed that non-health professionals from our sample perceived the social distance to alcoholics compared to the other four socially stigmatized groups in a similar way as in previous cases. According to nonhealth professionals, alcoholics could be better accepted than drug addicts; however, the other three groups were perceived as more favourable than alcoholics were $(Z$-values ranged from -9.126 to $-4.355, \mathrm{p}<0.001)$.

The second part of Table 6 (i.e. results obtained for health professionals) included findings that were similar to the previous ones in three out of four cases (social distance to alcoholics compared to that perceived toward homosexuals, individuals with some mental illness, and individuals with physical disability). The aforementioned differences were statistically significant at the 0.001 level. In addition, there was an interesting result with respect to social distances towards alcoholics and drug addicts. The average of negative ranks was higher than the mean of positive ranks (37.02 vs. 35.51). Furthermore, the difference between the participants' estimates was statistically significant $(Z=-2.456, p$ $<0.05)$. Therefore, health professionals perceived alcoholics as more socially distant than drug addicts.

As shown in Table 7, there were no statistically significant differences between males and females towards alcoholics $(\mathrm{U}=4841.5$, $Z=-1.874, p>0.05)$. Thus, females and males reported similar degrees of social distance toward this group of stigmatized indi- 
Table 7. Gender differences in social distance towards alcoholics

\begin{tabular}{lccccc}
\hline Gender & N & Mean Rank & $\begin{array}{c}\text { Mann- } \\
\text { Whitney U }\end{array}$ & Z & p \\
\hline Male & 72 & 127.26 & 4841.5 & -1874 & 0.061 \\
Female & 158 & 110.14 & & & \\
\hline
\end{tabular}

viduals. Additionally, males had higher mean rank (127.26) of their estimates, compared with females (110.14). The obtained $p$-value $(p=0.061)$ was close to 0.05 ; therefore, there is a possibility of obtaining statistically significant results in similar studies.

Despite the mean rank for social distance toward alcoholics in the sample of nonhealth professionals was greater than that of health professionals (117.44 vs. 113.62), this difference was not statistically significant $(U$ $=6391.0, Z=-0.451, p>0.05)$. Hence, social distance to alcoholics was not influenced by participants' profession.

\section{Discussion and Conclusions}

This research examined the problem of social distance (and stigma) toward alcoholics, compared to other high-risk social groups on the domestic sample, and determined attitudes were predominantly negative.

In relation to the first goal of the research to determine the differences in social distanc- es towards alcoholics as compared to some other socially stigmatized groups, the results showed that alcoholics are ranked second according to social distance. Only drug addicts are more stigmatized, while mentally ill individuals, homosexuals and individuals with physical disabilities are less stigmatized. All the established differences in social distances towards alcoholics and other observed groups have proven to be statistically significant.

Regarding the second goal of the research - to examine these differences with respect to participants' gender (males versus females) and profession (non-health vs. health professionals), in subgroups of different sex and occupation a similar pattern was found (rank-order) as in the total sample, with an exception of alcoholics were the most distinguished group among health professionals. The differences in social distance toward alcoholics and other observed groups have proven to be statistically significant in subgroups of different sex and occupation. No gender differences were confirmed in social distances towards alcohol-

Table 8. Differences in social distance with regard to participants' profession

\begin{tabular}{lccccc}
\hline Profession & $\mathrm{N}$ & Mean Rank & $\begin{array}{c}\text { Mann- } \\
\text { Whitney U }\end{array}$ & Z & p \\
\hline $\begin{array}{l}\text { Non-health professionals } \\
\text { Health professionals }\end{array}$ & 113 & 117.44 & 6391.0 & -0.451 & 0.652 \\
\hline
\end{tabular}


ics, and there were no differences between observed groups of occupations.

Results in this study concerning alcoholics and drug addicts are in concordance with previous studies. One possible explanation, as mentioned above, is that alcohol-dependent individuals, as well as drug users, are considered much more responsible for their condition $[9,27,33]$. In addition, in accordance with expectations, individuals with psychiatric disabilities were viewed more negatively than people suffering from physical disabilities but both were still viewed less negative than drug users and alcoholics [9,27]. It has also been shown that health professionals do not differ from the general population in their (prevailingly negative) attitudes, which is also the case in the quoted foreign studies [28-30,32,33].

Given the negative effects of stigma, the results point to the need for action in the direction of destigmatization of alcoholics, as well as other included high-risk social groups, in the population of both health and nonhealth professionals of both sexes.

"Affected individuals have a right to be judged by their personal behavior, not by the

\section{References}

1. Bagić A. Uloga socio-demografskih i iskustvenih čimbenika u formiranju stavova i socijalne distance prema epilepsiji i oboljelima (PhD thesis). Zagreb: School of Medicine, University of Zagreb; 2011.

2. Vukušić Rukavina T. Razvoj mjernog instrumenta za procjenu stigmatizacije duševnih smetnji u tiskanim medijima (PhD thesis). Zagreb: School of Medicine, University of Zagreb; 2011.

3. Link BG, Phelan JC. On stigma and its public health implications. Proceedings of the US NIH

Stigmatization of Alcoholics stereotypes attached to a diagnostic label. The goal of combating the stigma of alcoholism should not be to create a 'better', positive but similarly stereotypical, image of alcohol-dependent persons, but to give them a chance to be seen as individuals fighting a severe disorder and potentially changing their behavior and recovering from their illness" [33].

The importance of research and actions in this field derives from the association between perceived stigma and treatment, which has potentially important implications for initiatives that aim to reduce stigma toward alcohol-related disorders. Numerous studies have shown that negative attitudes toward mental illness can be reduced after educational interventions among health professionals, police, employers, and community workers [23].

\section{Acknowledgments}

None.

\section{Conflict of interest}

None to declare.

Conference on stigma and global health: Developing a research agenda, Bethesda MD; 2001.

4. Link BG, Phelan JC. Stigma and its public health implications. Lancet. 2006;367:528-9.

5. Thornicroft G, Rose D, Kassam A, Sartorius N. Stigma: ignorance, prejudice or discrimination? $\mathrm{Br}$ J Psychiatry. 2007;190;192-3.

6. Bogardus, E. S. Measuring Social Distance. J Appl Sociol. 1925;9:299-308.

7. Field D. The social definition of illness. In: Tuckett D, ed. An introduction to medical sociology. London: Tavistock Publications; 1976. p. 334-366. 
8. Reidpath DD, Chan KY, Gifford SM, Allotey P. 'He hath the French pox': stigma, social value and social exclusion. Sociol Health Illn. 2005;27:46889.

9. Albrecht GL, Walker VG, Levy JA. Social distance from the stigmatised: a test of two theories. Soc Sci Med. 1982;16:1319-27.

10. Jussim L, Palumbo P, Chatman C, Madon S, Smith, A. Stigma and self-fulfilling prophecies. In: Heatherton TF, Kleck RE, Hebl MR, Hull JG, eds. The social psychology of stigma. New York: The Guilford Press. 2000. p- 374-418.

11. Scambler G. Re-framing stigma: felt and enacted stigma and challenges to the sociology of chronic and disabling conditions. Soc Theory Health. 2004:2:29-46.

12. Giorgianni SE. Media images and messages about stigma: The good, the bad and the ugly. The Pfizer Journal. 2004;5:26-29.

13. Van Brakel WH, Anderson AM, Mutatkar RK, Bakirtzief Z, Nicholls PG, Raju MS, Das-Pattanayak RK. The Participation Scale - Measuring a key concept in public health. Disabil and Rehabil. 2006;28:193-203.

14. Rao D, Choi SW, Victorson D, Bode R, Peterman A, Heinemann A, Cella D. Measuring stigma across neurological conditions: the development of the stigma scale for chronic illness (SSCI). Qual Life Res. 2009;18:585-95.

15. Corrigan PW, Lurie BD, Goldman HH, Slopen N, Medasani K, Phelan S. How adolescents perceive the stigma of mental illness and alcohol abuse. Psychiatr Serv. 2005;56:544-50.

16. Ahern J, Stuber J, Galea S. Stigma, discrimination and the health of illicit drug users. Drug Alcohol Depend. 2007;88:188-96.

17. Fortney J, Mukherjee S, Curran G, Fortney S, Han $\mathrm{X}$, Booth BM. Factors associated with perceived stigma for alcohol use and treatment among at-risk drinkers. J Behav Health Serv Res. 2004;31:418-29.

18. Stuber J, Galea S, Link BG. Smoking and the emergence of a stigmatized social status. Soc Sci Med. 2008;67:420-30.

19. Room R. Stigma, social inequality and alcohol and drug use. Drug and Alcohol Rev. 2005;24:143-55.
20. Zhang L, Wieczorek W, Welte J. The nexus between alcohol and violent crime. Alcohol Clin Exp Res. 1997;21:1264-71.

21. Jokić-Begić N, Kamenov Ž, Lauri Korajlija A. Kvalitativno i kvantitativno ispitivanje sadržaja stigme prema psihičkim bolesnicima. Socijalna psihijatrija. 2005;33;10-9.

22. Adlaf EM, Hamilton HA, Wu F, Noh S. Adolescent stigma towards drug addiction: Effects of age and drug use behavior. Addict Behav. 2009;34:3604.

23. Keyes KM, Hatzenbuehler ML, McLaughlin KA, Link B, Olfson M, Grant BF, Hasin D Stigma and Treatment for Alcohol Disorders in the United States. Am J Epidemiol. 2010;172:1364-72.

24. O'Connor LE, Berry JW, Inaba D, Weiss J, Morrison A. Shame, guilt and depression in men and women in recovery from addiction. J Subst Abuse Treat. 1994;11:503-10.

25. Brown SA. Standardized measures for substance use stigma. Drug Alcohol Depend. 2011;116:13741.

26. Rao H, Mahadevappa H, Pillay P, Sessay M, Abraham A, Luty J. A study of stigmatized attitudes towards people with mental health problems among health professionals. J Psychiatr Ment Health Nurs. 2009;16:279-84.

27. Corrigan PW, Kuwabara SA, O'Shaughnessy J. The public stigma of mental illness and drug addiction: findings from a stratified random sample. J Soc Work. 2009;9:139-47.

28. Schulze B. Stigma and mental health professionals: a review of the evidence on an intricate relationship. Int Rev Psychiatry. 2007;19;137-55.

29. Mental Health Council of Australia. Consumer and carer experiences of stigma from mental health and other health professionals. Canberra; MHCA; 2011.

30. Ahmedani BK. Mental Health Stigma: Society, Individuals, and the Profession. J Soc Work Values Ethics. 2011;8:41-416.

31. Thornicroft G, Rose D, Kassam A. Discrimination in health care against people with mental illness. Int Rev Psychiatry. 2007;19:113-22.

32. Gilchrist G, Moskalewicz J, Slezakova S, Okruhlica L, Torrens M, Vajd R, Baldacchino A. Staff regard 
towards working with substance users: a European multi-centre study. Addiction. 2011;106:1114-25.

33. Schomerus G, Lucht M, Holzinger A, Matschinger H, Carta MG, Angermeyer MC. The Stigma of Alcohol Dependence Compared with Other Mental Disorders: A Review of Population Studies. Alcohol Alcohol. 2011;46:105-12.
34. Carija M. Stigma zdravstvenog osoblja prema psihičkim bolesnicima (unpublished graduate thesis). Zagreb: Department of Psychology, Faculty of Humanities and Social Sciences, University of Zagreb; 2008.

\section{Stigmatizacija alkoholičara i drugih visoko rizičnih socijalnih skupina - odnos sa spolom i vrstom zanimanja}

Sažetak - Uz probleme u funkcioniranju koji proizlaze iz činjenice da pripadaju određenim osjetljivim socijalnim kategorijama (osobe s kroničnim bolestima i stanjima, pripadnici manjinskih i marginaliziranih skupina i dr.), pripadnici tih skupina suočavaju se i s osjećajem distanciranja i/ili odbacivanja od strane drugih ljudi, uključujući i zdravstveno osoblje. Glavni cilj ovog istraživanja je utvrditi socijalne udaljenosti prema alkoholičarima u usporedbi s pojedinim drugim visoko rizičnim socijalnim skupinama, te provjeriti eventualne razlike u socijalnim udaljenostima (i stigmatizaciji) alkoholičara s obzirom na spol i vrstu zanimanja. Na uzorku od 230 ispitanika (namjernog uzorka zdravstvenih i nezdravstvenih djelatnika, heterogenih po sociodemografskim obilježjima) primjenom Bogardusove ljestvice socijalne distance ispitivana je socijalna distanca prema određenim socijalnim skupinama: narkomanima, alkoholičarima, homoseksualcima, psihički bolesnim osobama i osobama s tjelesnim invaliditetom. Rezultati su pokazali da su osobe s tjelesnim invaliditetom najmanje stigmatizirana skupina, a najstigmatiziraniji su narkomani, dok su alkoholičari po socijalnoj distanci na visokom drugom mjestu. Sličan trend pronađen je i unutar skupina ispitanika različitog spola, kao i vrsta zanimanja, s tim da su se kod zdravstvenih djelatnika alkoholičari izdvojili kao najstigmatiziranija skupina, dok su se narkomani našli na drugom mjestu. Spolne razlike u socijalnoj distanci prema alkoholičarima nisu potvrđene, kao ni razlike među dvije promatrane skupine zanimanja. Rezultati istraživanja daju načelne smjernice potrebne za osmišljavanje procesa destigmatizacije alkoholičara, ali i drugih ispitivanih rizičnih socijalnih skupina, u populacijama zdravstvenih i nezdravstvenih djelatnika oba spola.

Ključne riječi: visoko rizične socijalne skupine, alkoholičari, socijalna distanca, stigma, zdravstveni i nezdravstveni radnici 
